\title{
Intermingling of History and Politics in The God of Small Things
}

\author{
Md. Abdul Momen Sarker1, Md. Mominur Rahman 2 \\ ${ }_{1}$ Department of English, World University of Bangladesh, Bangladesh \\ ${ }_{2}$ Social Worker and Researcher, Bangladesh
}

Md. Abdul Momen Sarker, E-mail: sarker10march@gmail.com

\section{ARTICLE INFO}

Article history

Received: March 14, 2018

Accepted: June 21, 2018

Published: August 31, 2018

Volume: 9 Issue: 4

Advance access: July 2018

Conflicts of interest: None

Funding: None

\section{Key words:}

Socio-Political,

Indian Culture,

History,

Communism and Feminism

\begin{abstract}
Suzanna Arundhati Roy is a post-modern sub-continental writer famous for her first novel The God of Small Things. This novel tells us the story of Ammu who is the mother of Rahel and Estha. Through the story of Ammu, the novel depicts the socio-political condition of Kerala from the late 1960s and early 1990s. The novel is about Indian culture and Hinduism is the main religion of India. One of the protagonists of this novel, Velutha, is from a low-caste community representing the dalit caste. Apart from those, between the late 1960s and early 1990 s, a lot of movements took place in the history of Kerala. The Naxalites Movement is imperative amid them. Kerala is the place where communism was established for the first time in the history of the world through democratic election. Some vital issues of feminism have been brought into focus through the portrayal of the character, Ammu. In a word, this paper tends to show how Arundhati Roy has successfully manifested the multifarious as well as simultaneous influences of politics in the context of history and how those affected the lives of the marginalized. Overall, it would minutely show how historical incidents and political ups and downs go hand in hand during the political upheavals of a state.
\end{abstract}

\section{INTRODUCTION}

This novel focuses on one of India's negligible religious minorities, the Syrian-Christians. Throughout the novel, we find references to the history of the Syrian-Christians and their struggle to cope with the local Hinduism-based social structure. In $52 \mathrm{CE}$, the apostle St. Thomas came to India near the port of Cranganore. He influenced a number of Hindu and Jewish people to convert their religions. Besides, he founded seven churches. With the British establishing their colonial political power in the region in the early $19_{\text {th }}$ century, the minorities found themselves in a fresh western colonial influence. In 1816, the British government sent missionary to preach Christianity from the Church of England's 'Church Missionary Society'. They assisted the Syrian-Christian church but never interfered. In The God of Small Things when Velutha's grandfather converted himself to avoid the torment of the life of an untouchable, the Anglicans church took the opportunity. But the church found him still as a 'Rice-Christian' (Ch. 2, P. 74). In the 1830s, some Syrian Christians, in spite of being influenced by the Anglican missionaries, initiated a reformation movement led by a seminary teacher Palakunnathu Abraham Malpan. The movement was, in different ways, similar to the Protestant Movement like reviving spirit of the original Biblical instruction. But the movement was not devoid of the essence of Eastern Church also. In the first chap- ter of the novel, we find Estha and Rahel's great grandfather to be a former priest of the Mar Thoma church. This church was recognized as separate church tradition and this point has some relevance when we recall Chacko's self-mocking statements about the family's Anglophilia.

\section{Untouchability and the Caste System in Hinduism}

The idea of caste is supported by some early myths of Hinduism. Such as, in Rig Veda, caste is associated with the creation of myth of Purusa, which is the primal celestial man out of whom the universe was created. The creation and demarcation of the whole human race into four different social orders is associated with the sacrificial diagnosis of this cosmic creature as Wendy O' Flaherty says,

"When (the gods) divided the Man, into how many parts did they disperse him? What became of his mouth, what of his arms, what were his two thighs and his two feet called? His mouth was the Brahmin (the priest class), his arms were made into nobles (ksatriyas), his two thighs were the populace (vaisyas), and from his feet the servants (sudras) were born. The moon was born from his mind; the sun was born from his eye." (p. 28)

Most of the historians agree to a common matter, that is, the idea of cast identification in primitive India came from 
the diversified occupation of the inhabitants. In this regard,

K. M. Sen states:

"The division of the society into four castes has, in all probability, always been theoretical, for, from the earliest time, we find references to a much more complicated caste structure the occupational divisions with which castes were associated give us a better view of the role of castes in the working of society.“(p. 28, 29)

Caste system is considered a way of understanding Hinduism and India, like many other historical archives, by the European Orientalists. Simultaneously, they hold the caste system responsible for both the cause and effect of India's economic and political drawback and India's failure to save or protect itself from the invasion and conquest by outsiders. Hence, Britain found a perfect propaganda in caste system to penetrate India and establish colonization as they successful-ly hegemonized India by making belief that India cannot protect itself, hence it needs a protector. Even so, the 'invasion' model became highly influential and later formed the basis for Hindu nationalist readings of history.

During the struggle for independence, M. K. Gand-hi stood by the untouchables and renamed them Harijans meaning children of God. He tried to ensure their access to temples. But he never tried to relieve them from their heinous job like sweeping and latrine-cleaning, as Mulk Raj Anand wrote in his novel Untouchable, 'He is dirty because he cleans gentlemen's dirt'. (Page number?)

In The God of Small Things Roy explains the devastating sense of caste inadequacy felt by elder untouchables like Velutha's father, Vellya Paapen, as a product of Kerala's ancient, inbuilt rules of caste, characterized in the 'Crawling Backwards Days' of the pre-liberation period, when Para-vans were not permitted to commute on the roads freely, not permitted to wear clothes in their upper bodies, not allowed to use umbrellas. In January 1999, at a meeting in Calicut, Roy pledged the royalties of the Malayalam translation of The God of Small Things to the Akademi 'in memory of Ve-lutha'. Speaking to the audience in Malayalam, she stated

"I know that you share the anger at the heart of The God of Small Things. It is an anger that the 'modern' metropolitan world, the other India, the one in which I now live, tends to overlook, because for them it is something distant, something unreal."

\section{The Naxalites and Environmental Protest Movements}

The naxalites had been revolutionaries who initiated an armed civil disobedience within the northwest Bengal village of Naxalbari in March 1967. Often peasants, untouchables and people of the nearby Santal tribe angered via years of empty government guarantees, the Naxalites advocating a logo of communism derived from the teachings of the Chinese leader Mao Tse-Tung - attacked Hindu Zeminders and quickly won management of the district. The movement was supported with the aid of China and, even though some of the Naxalbari revolutionaries had been killed in the brutal government suppression of the insurrection, the rebellion quickly spread to other states along with Andhra Pradesh, Bihar, Kerala and Uttar Pradesh.
In The God of Small Things, Velutha is alleged to have joined the Naxalites in his four years absence from Ayemenem (Ch. 2, P. 77), and despite the fact that his being killed by the police is not always a response to activist rebellion, it nevertheless parallels, in its 'sober steady brutality' (Ch. 18, p. 308), the now infamous violence meted out to the Naxalite revolutionaries, who had been tortured, raped and accomplished via police inside the pay of coalitional communist kingdom governments. Because of the impressionistic atmosphere of her presentation of Naxalite politics as a chain of emotional nation inclusive of anger and a worry of dispossession, it's far tough to choose precisely how a long way we ought to study Roy's comments about the Naxalite opponents as an endorsement in their revolutionary goals. She has finally stated in interview that while the 'pros and cons of violent and nonviolent resistance can be debated', there may be no question that violent resistance harms girls physically and psychologically in deep and complex approaches. If we take her later essays into consideration, then Naxalbari may be greater important in The God of Small Things as a natural signal of radical dissent - as such, the rebellion works in Roy's novel because the symbolic counterpart to the modern taboo-breaking transgression represented with the aid of Ammu and Velutha's affair, an act which can also be interpreted as a bodily, fatal protest towards ancient oppressions.

There might also be more grounds why Naxalbari has so much symbolic significance in The God of Small Things. At one stage, Roy's references to the Naxalites cannot be separated from the type of retro-revolutionary nostalgia that, in the west, has efficiently repackaged Che Guevara as a style icon who became the photogenic Argentinean revolutionary and who took component in Fidel Castro's communist coup in Fifties in Cuba. The distinction, as the cultural critic John Hutnyk argues, is that for writers, artists and musicians in India and in the Indian diaspora, Naxalbari may additionally provide an opportunity to the insipid Bollywood way of life that represents them globally.

For Roy, progress and advancements in agriculture and hydroelectric plants like the Narmada dam ventures have confiscated India's most defenseless marginalized groups in the name of advancement. In Roy's view, the Western idea of improvement, when connected to India, uncovers a significant absence of creative ability, and by aimlessly following a formative way, the Indian state, which sought outside venture as a major aspect of its monetary advancement in the mid 1910s, has devastated its own nationals and end up entangled in degenerate management of worldwide multinationals, for example, the vitality of goliath Enron. The effect of outside speculation and India's expanded financial development rate is obvious in The God of Small Things in the way the residential community of Ayemenem changes and moves toward becoming globalized between the two time plans of the novel; its tenants get themselves ready to profit working miserably in the inlet states, however their new riches exists together with expanded destitution and sketchy imports, for example, tourism and satellite TV.

Without particular approaches to target destitution, contends the history specialist Sunil Khilnani, financial progression is probably going to build social imbalances in India 
in a few ways: broadening aberrations in social open doors honing the separation amongst country and urban India and expanding contrasts in riches between districts. A lot of Roy's writings since The God of Small Things has scrutinized the predominance of the story of neo-liberal free enterprise, and her help for bunches like the NBA can be viewed as an endeavor to secure its choices - political stories 'that are not quite the same as the ones we are being mentally programmed to accept'. For Roy, India's political alternatives are local: 'Decentralized economics, decentralized control; handing some measure of power back to the people' (127). What's more, at last, her political expectations are established on India's inborn protection from a solitary thought. Like her vision of the novel as a story that cannot be told in one way, India's future depends, in her work, on its majority: "India's redemption lies in the inherent anarchy and fractiousness of its people and its political formations. Corporatizing India is like trying to impose an iron grid on a heaving ocean, forcing it to behave. My guess is that India will not behave. It cannot. It's too diverse, too grand, too feral, and eventually, I hope - too democratic to be lobotomized into believing in one single idea, which is, eventually, what corporate globalization really is: Life is Profit." (p. 128)

\section{Communism in Kerala}

In March 1957 Kerala turned into the main Indian state and in fact, the primary government in the world to choose a communist government in a democratic way. Instead of embracing savage upset, the gathering pioneer, E. M. S. Namboodiripad, proposed a 'quiet' change to socialism and in The God of Small Things Roy draws in with the political inheritance of socialism in Kerala in her humorous depiction of Namboodiripad himself and his gathering devotees. Marxism had been a component of Indian legislative issues since the 1920s, and after freedom the Congress government embraced conspicuously communist financial strategies. As Roy plots in The God of Small Things, the principal time of comrade lead in Kerala, amid which 'the communists wound up in the phenomenal - pundits said preposterous - position of governing a people and incite upheaval all the while' (Ch. 2 P.67), arrived at a quick end after they presented disagree-able bills, for example, the completion of concessionary charges for understudies, and confronted strikes and common distress. The past caused issues down the road for the CPI in 1964, when the gathering was rived over assertions that their director had offered to turn source for the British amid the 1920s in return for his own discharge from jail. A split had effectively framed because of isolated loyalties amid the war amongst China and India in 1962, and the initiative outrage incited various CPI individuals to leave and shape the Communist Party of India (Marxist) or CPI (M). The CPI (M), under the course of E. M. S. Namboodiripad, considered itself to be the 'genuine inheritor of the unified CPI', and focused on creating rustic power bases at a local as opposed to national level, picking up an unexpected triumph in the 1967 races in Kerala as a component of a seven-party hostile to Congress coalition with the more seasoned CPI. This second comrade organization went on for thirty-one months previously capitulating to inner clash, however the communists remained in office as a major aspect of different coalition gathering and remain a dynamic nearness in the legislative issues of the state.

On the off chance that the CPI truly assumed such a constrained part in national legislative issues, for what reason did it turn into an effective power in Bengal and Kerala? In The God of Small Things, this is an inquiry 'even Chacko has no real complete explanation for', however which Roy tries to reply in a curiously nitty gritty aside. The primary purpos-es of her contention merit reconsidering here:

"There were several competing theories. One was that it had to do with the large population of Christians in the state. Twenty percent of Kerala's populations were Syrian Christians. Structurally - this somewhat rudimentary argument went - Marxism was a simple substitute for Christianity. Replace God with Marx, Satan with the bourgeoisie, Heaven with a classless society, the Church with the Party, and the form and purpose of the journey remained similar." [Ch. 2, p. 66]

Roy's textual digression into the historical backdrop of socialism in Kerala additionally relates a 'second theory' which credits the socialist triumph to the broadly elevated amounts of proficiency in Kerala, despite the fact that, slag her narrator calls attention to, these education levels were accomplished generally in view of the comrade organization. As indicated by the narrator of The God of Small Things, the most conceivable explanation behind the socialist accomplishment in Kerala - one that The God of Small Things is disloyalty plot fortifies - is that the Communist Party worked inside the current power structure:

"The real secret was that communism crept into Kerala insidiously. As a reformist movement that never overtly questioned the traditional values of a casteridden, extremely traditional community. The Marxists worked from within the communal divides, never challenging them, never appearing not to. They offered a cocktail revolution. A heady mix of Eastern Marxism and orthodox Hinduism, spiked with a shot of democracy." [Ch. 2, p. 66-7]

However, does this political settlement of the current position structure signify a verifiable treachery of lower-rank gatherings by the CPI (M) in Kerala? In his authentic overview of the socialist party in Kerala, Menon proposes that their political procedure was not to recognize totally with any gathering: "The career of the party has been characterized by political pragmatism rather than permanent affiliations of any kind. There have been conjectural and tactical partnerships with parties and groups of all hues, justified by theoretical legerdemain'. (p.193). The procedures venturesome parts of the CPI (M), and its developing lack of

concern,- are enlisted in Roy's novel in the vile figure of Comrade K. N. M. Pillai, a pessimistic agitator whose house, once a hotbed of study gatherings and progressive support, is currently improved with limp, blurred gathering banner from which, unexpectedly, the 'red had bled away' (Ch. 1, p. 13).

If it were not her doubt about the certain misuse of supremacy on a nationwide altitude, we might be forgiven for seeing in Roy's novel a secret resistance of the biased, capi- 
talist Marxism of the Nehru period. Yet, in her frequent proclamation of the necessity for political demonstration to have effect on a tiny, liable degree, her politics are in fact more evocative of Gandhi's dream of society like an assemblage of autonomous villages. As Roy comments in interview, to see a better India, focus must be on local life and culture: 'Decentralized economics, decentralized control; handing some measure of power back to the people.' Simultaneously, Roy is intensely doubtful of the narrow-mindedness of rural life and alerts that she is not 'a proselytizer for the eternal upholding of custom and tradition.' This is maybe why her best political portrayal in The God of Small Things is held not for Gandhi's thoughts or his political successors like Vi-noba Bhave, however for a left-wing progressive gathering that embraced fiercer, uncompromising techniques: the Naxalites.

\section{Gender Politics and Sexuality}

If Roy's novel is imagined in musical terms, the oppression of women forms vital catchphrase that persists, in a range of embellishment, all through the novel. "What was it that gave Ammu this Unsafe Edge? It was what she had battling in-side her. An unmixable mix. The infinite tenderness of moth-erhood and the reckless rage of a suicide bomber' (Ch. 2, p. 44).

At the point when Ammu endeavors to assert acknowledgment under the law by creating an impression at the police headquarters after Velutha's capture, the police reviewer declines the announcement, attacks her calling her a veshya or whore. These days, the twofold colonization that detains ladies in post-freedom Kerala is more averse to appear as an arrangement between onerous conven-tional qualities and imperialism than amongst custom and neofrontier parts of globalization, for example, the typifi-cation ladies in the worldwide media. As Roy calls attention to in one of her meetings in the book The Chequebook and the Cruise Missile: "A lot of the women who are involved in resistance movements are also redefining what 'modern' means. They are really at war against their community's traditions, on the one hand, and against the kind of modernity that is being imposed by the global economy, on the other. They decide what they want from their own tradition and what they will take from modernity. It's a high-wire act." (p. 125, 126)

During and before independence in 1947, Indian women were not aware of their legal or human rights, hence they never claimed it. The government never paid enough attention to the feminist issues and never took step to educate women properly. However, in specific cases, the rights that could be claimed by the most of the women in India were perched by older laws which concerned particular marginal communities. Significant examples of this are the Travancore Christian Succession Act of 1916 and the Cochin Christian Succession Act of 1921. These laws were applicable only to the Syrian-Christian minority as well as severely confined the heritage rights of Syrian-Christian women. Arundhati Roy's mother, Mary Roy who were a divorcee and daughter of a Syrian-Christian man, would ef- fectively plea aligned with these acts in the Indian Supreme Court in 1986. In The God of Small Things it is observed that the intersecting forms of subjugation that Ammu faces are further reinforced by her poor legal status or locus stand I or, as her children misinterpret it, her lack of 'Locusts Stand I', as a Syrian-Christian woman (Ch. 2, p. 57). By including references to the legal inequality between Ammu and her brother Chacko - who recognizes his own pow-er of inheritance by telling her 'what's yours is mine and what's mine is also mine' (Ch. 2, p. 57). Roy draws attention, obliquely, to a history of dispossession and a struggle for women's rights in which her own mother was deeply involved.

The legal and social forces that conspire against Ammu in The Gold of Small Things and create a situation where 'there would be no more chances' (Ch. 2, p. 43) are especially disturbing when we recall that, by the late 1960s, Kerala was starting to gain a reputation as a social and economic success story.

Ammu's perilous periphery is a threat to the established order, because it not only bears the promise of her rapid challenging of sexual taboo but also brings into play evidently unmixable characteristics of her sexuality that contemporary Indian society, especially caste laws used to normally keep aloof. In some remarkable ways, the ta-boobreaking force of Ammu's sexuality is evocative of powerful Hindu deities, like the demolisher goddess Kali, manifestation of godly vigor or shakti, who were assembled as political cryptogram in the early nationalist revolution and who have since been re-appropriated by Hindu feminists. As Radha Kumar reminds us, one of the most significant expansions in Indian women's demands for indiscrimination has been a shift away from the unease for women's bodies as locations of ethnic and national revival, towards more rights-based statements that women's bodies should not be treated as the focus of social control. It is the truth of her maternal status that makes Ammu such an easy issue of social control, and her response to her children, whom she loves intensely but describes in a moment of rage as the 'millstones around my neck' (Ch. 13, p. 253), accentuates this tension.

\section{CONCLUSION}

The novel deals with the social and political problems of Kerala. It also puts emphasis on the history of social structure and political movements of that province. It is imperative to note that the novel does not describe the political upheavals chronologically, rather it brings into focus those incidents of history and politics which are intensely associated with the lives and struggles of the characters. The paper has analyzed how multifarious roles of history and politics influenced and affected the lives of people in different ways. Consequently, everything here in this novel has been described through different incidents and speeches of the characters. Furthermore, Roy tries to shed light on the deteriorated condition of wom-en and lower-caste people in the context of Varna system of Hinduism. 


\section{REFERENCES}

Barsamian, David. The chequebook and the cruise missile: conversations with Arundhati Roy. London, Harper Perennial, 2004. Print.

Chakravarti, Uma. Gendering Caste Through a Feminist Lens. Calcutta: Street, 2006. Print.

Doniger, Wendy, editor. Hindu Myths. Harmondsworth, Pen-guin Books, 1975. Print.

Khilnani, Sunil. The Idea of India. Harmondsworth, Penguin Books, 1997. Print.

Kothari, Rajni, ed. Caste in Indian Politics. Hyderabad: Ori-ent Longman Limited, 1970. Print.

Kumar, Sangeet. Changing Role of the Caste System: A Critique. Jaipur: Rawat Publication, 2005. Print.

Menon, Dilip M. Caste, Nationalism and Communism in South India: Malabar 1900-1948. Cambridge University Press, 2007. Print.
Roy, Arundhati, Power Politics, 2nd ed. Cambridge Mass: South End Press, 2011. Print.

---The God of Small Things. New Delhi: Penguin Books, 1997. Print.

--- (1993, February 12). 'I give you my book in memory of Velutha'.

Sen, K.M. Hinduism. Harmondsworth, Penguin Books, 1991. Print.

Searle-Chatterjee, Mary, and Ursula Sharma. Contextualising Caste: Post-Dumontian Approaches. Rawat, 2003.

Thapar, Romila. A History of India. England: Penguin Books, 1966. Print

Tickell, Allex, "The God of Small Things: Arundhati Roy's Postcolonial Cosmopolitanism", The Journal of Commonwealth Literature, 38, 2003. Print. 